\title{
Metaphor through the lens of linguosynergetics (Exemplified by the concept "DEATH" in Terry Pratchett's discourse)
}

\author{
Rakhim Z. Muryasov - Anna S. Samigullina - Andrey G. Bakiev
}

DOI: $10.18355 /$ XL.2018.11.03.13

\begin{abstract}
The article presents a linguosynergetic approach to the study of metaphors. Having an inherent interdisciplinary character synergetics opens new perspectives for the research of various linguistic phenomena. The synergetic methodology is applied to the object of the current study - a metaphor. The metaphorization is not regarded as a unidirectional linear projection of meanings; it is a synergetic interaction of two or more input domains. The authors observe a non-linear interaction of order parameters (meanings and connotations that characterize the concepts of source and target domains). That interaction results in the formation of a new conceptual unit that has its own identity - a completely new set of meanings. The authors apply the synergetic methodology to study metaphors with the target-domain "death" in the literary discourse by Terry Pratchett. It is worth mentioning that at the level of discourse the concept "death" unfolds along the tree-like trajectory, which explicated a logical, gradual meaning cohesion and the dual nature of the concept. In the beginning, the death is primarily associated with the conventional personification of death - Grim Reaper. Gradually the image of Grim Reaper transforms into the image of a positive character Kind Reaper who has to perform his duty.
\end{abstract}

Key words: metaphor, linguosynergetics, order parameter, order, chaos, fluctuation, bifurcation point, fractal, rhizome

\section{Introduction}

The article under consideration gives insight into the process of metaphorical meaning-making in the light of the synergetic approach to language.

The purpose of the article lies in the presentation of the metaphorization process as a synergetic interaction of two conceptual systems and order parameters - meanings that are associated with them. This nonlinear interaction results in the formation of a new concept - blend that in its turn generates new meanings.

The end of the twentieth century is marked by the shifts of scientific paradigms and reconsideration of former methodological principles that led to the formation of new scientific approaches. Many scholars as post-neoclassical characterize the modern stage in science (Tarde, 1969; Levinson, 1983; Thornbury, 1991; Thompson, 1995; Fauconnier, 1997; Jamieson, Campbell, 1997; Vodak, 1997; Nerlich, Clarke, 2001; Dijk, 2002; Caballero, 2003; Köhler, 2005; Budd, 2006; Steger, 2007; Muryasov, Samigullina, 2013; Raymond et al., 2013; Rixon, 2014; Strauss, 2014; Vhenttonen et al., 2014; Zheltukhina, Magomadova, 2015; Davydyuk, Panasenko, 2016; Tantucci, 2016; Zheltukhina et al., 2016; Bobyreva et al., 2017; Golubkova, Masalimova, Birova, 2017; Li, Pyrkova, Ryabova, 2017; Zheltukhina et al., 2017; Grecmanova, Dopita, Urbanovska, 2017; )

A range of new discoveries served as a driving force for the formation of new interdisciplinary methodological principles as opposed to the ones that were no longer capable of solving the problems of the modern time. Primarily these are breakthroughs in the field of chemistry and physics, namely the discovery of laser generation by H. Haken (1983), the theory of dissipative structures by I. Prigogine and I. Stengers (1984), the theory of turbulence by A. Kolmogorov (Parthasarathy, 1988 ) and many others. In these phenomena, one could observe regularities in the process of self-organization of units of systems when undergoing certain stages from 
chaos to order. H. Haken (1983) explained it is referring to the synergetic mechanism that is spontaneously implemented when a system deviates from equilibrium.

Synergetics (from Greek assistance, cooperation, complicity) is an interdisciplinary science explaining the formation and self-organization of patterns and structures in open dissipative systems far from equilibrium. The German theoretical physicist $\mathrm{H}$. Haken (1983), a professor at the University of Stuttgart, first introduced the term "synergetics." When conducting the research of generation processes in the laser system the scientist concluded, the phenomenon of self-organization of active atoms may take place under the influence of factors, which deviate the system from the state of equilibrium (Haken, 1983).

Further, the scientist discovered similarities in the process of self-organization of units of systems in related fields of science, thereby deducing synergetics beyond the boundaries of natural sciences and giving it an interdisciplinary character. H. Haken (1983) discovered similarities in the behavior of a multitude of individual units of different levels (atoms, molecules, cells, groups of people, etc.), and came to the conclusion that, ultimately, their own fate is determined by them in the course of interaction with one another via competition, on the one hand, and cooperation - on the other.

\section{Methodology}

Before proceeding to methodological aspects of synergetics, it is necessary to define its main categories. We should point out that synergetics methodology can be applied only to open, nonlinear, dissipative, dynamic systems. The vast majority of systems that surround us including the language possess these properties. Thus, synergetics claims the right to create a single unified methodological approach to study manifold phenomena of the surrounding reality.

The notions "order" and "chaos" are of paramount importance for synergetics. The order is a particular state of a system that is characterized by a strict arrangement and symmetry of the elements within it. The order is maintained by certain variables order parameters that determine the course of development of a system. According to H. Haken (1983), in many cases, the behavior of a system close to instability points can depend on a very few variables, which ultimately determine the behavior of the entire system. In addition, the system might be regulated by several order parameters, in other words - courses of development of the system. The simultaneous "coexistence" brings about a "competitive struggle" for the "right" to determine the development of the system. Order parameters act in accordance with attractors of the system. By attractors, we mean a relatively stable, equilibrium state of the system, to which the whole set of trajectories are directed.

A fundamentally important achievement of synergetics is recognition of the overwhelming majority of surrounding systems as open and dissipative, and thus capable of continuous exchanging of energy, information, momentum, etc. with the external environment. At the same time, dissipation also implies vulnerability of the system to external fluctuations - spontaneous deviations, oscillations from equilibrium.

Instability is one of the essential factors responsible for the rearrangement of the system. At a time of utmost instability, the system can either collapse or change its structure abruptly under the influence of even minor effects (jokers). At this point, it is impossible to predict what direction the system will take since the effect of any fluctuation can be decisive in the course of evolutionary development of the system. In the theory of synergetics, coincidence plays a key role. As G.A. Köhler and R.G. Piotrovski (2005) states the damping or the growth of external influence does not depend on the system itself, so it is impossible to predict the fate of the system near the critical point X (the bifurcation point). Any contingency (joker) can lead to the

XLinguae, Volume 11, Issue 3, June 2018, ISSN 1337-8384, eISSN 2453-711X 
destruction of the system and at the same time bring about a new course of development. Traditionally, contingency was defined as the lack of regularity. In a synergetic sense, contingency is close to such concepts as spontaneity, independence, freedom, heterogeneity, chaos. This feature of non-equilibrium systems is vividly described in E. Lawrence's metaphor "butterfly effect" (Hilborn, 2004). The scientist described the extreme vulnerability of non-equilibrium systems to external fluctuations and the crucial role of contingency in determining the course of development at the bifurcation point (Hilborn, 2004).

Bifurcation is the act of a spontaneous, unpredictable division of the initially homogeneous process or course of events. The process itself can generate many fragmentations of individual branches as poly-furcation. The bifurcation point manifests a violation of the stability of the evolutionary system; it is kind of a turning point, after which a qualitative change of the system occurs through chaos. It is worth mentioning that the former scientific paradigms regarded chaos as a destructive force. Chaos refers to dissipative processes - dissemination of previous information, meaning, energy, forces acting in accordance with the attractor as a factor of selforganization of a new order. Inside the chaos, a new system order and a new mechanism of self-organization are established. Chaos and order are two kinds of realization, two states in which the same system can exist.

Nowadays we observe the active integration of synergetics into the humanities and linguistics in particular. The object of research in this paper is the metaphor and the regularities of the metaphorical meaning-making process in the literary discourse produced by the English writer Terry Pratchett (1983; 1987; 1994; 1998).

In the course of analysis, we applied a number of general and specific methods to the object of study, that is, the metaphor. In the first place, it is the scientific method of linguosynergetics, which includes fractal-modeling techniques in synthesis with a classical two-space model of metaphor formation of J. Lakoff and M. Johnson (2003), and four-space model of metaphor formation of J. Fauconnier and M. Turner (2002).

\section{Results and Discussion}

Initially, we identify order parameters of the concepts representing the target-domain and the source domain. Order parameters are variables that maintain the order in the system up to a certain point of its development. In other words, order parameters are conventional ideas representing the conceptual systems. For that, we refer to the dictionary definitions in order to reveal the conventional ideas behind these concepts existing in the English-speaking culture. While describing them, we take into account the following characteristics of the concepts:

\section{1) Motion / state; \\ 2) Character of motion / state; \\ 3) Localization in space / time; \\ 4) Participant; \\ 5) Aim; \\ 6) Result;}

7) Accompanying elements.

Secondly, we apply the conceptual integration technique elaborated by G. Fauconnier and M. Turner (2002) in order to analyze metaphorical units. The method presumes a four-space model of metaphorization process: two input spaces (target and source domains), the generic space and the blended space. The key point of the conceptual blending theory is that metaphorization is not a unidirectional interjection of a concept from source-domain to the target domain. It is a dynamic process of integration of input spaces and its elements. In other words, we observe the synergetic interaction of order parameters of two conceptual systems representing the target and source domains. This interaction results in the formation of a new conceptual unit - a blend. On the one hand, the blend retains some signs of input spaces, and on the other, it is 
not their linear sum. From the standpoint of synergetics, the blend is an open emergent structure that acquires its own identity and presents a new order. Thus, we can conclude that the blend generates its own order parameters - new senses and meanings. That marks the transition of the system to a new level of organization (Fauconnier, Turner, 2002).

Thirdly, at the level of discourse (macro-level), the process of metaphorical meaningmaking can be analyzed with the help of fractal modeling. This method is based on the theory of A.N. Baranov (2003) of the types of compatibility of metaphorical meanings (strong, moderate, weak types of connection), and on the other hand, on the postulates of fractal geometry in science. Thus, we can distinguish three fractal trajectories of metaphoric meaning-making at the level of discourse, namely the trajectory of the spiral (strong type of connection, progressive and dynamic development of the meaning), the tree (moderate type of connection and logical meaning development), rhizome (weak type of connection and chaotic development of meaning) (Samigullina, Bakiev, 2014).

In this paper, we single out the concept death for the analysis as it has undergone the most significant interpretation in the literary discourse of T. Pratchett. In the semantic sense, this concept represents the end of the earthly life of a person and simultaneously the transfer to the afterlife.

In order to define the order parameters of the concept of death, we will turn to its dictionary definition. As it has already been mentioned, order parameters of the concepts corresponding to the conventional ideas about them that exist in the Englishspeaking culture. The reference to the dictionary definitions and its subsequent analysis most exhaustively explicates the parameters, which in synergetic sense ensure a stable, unambiguous perception of the concepts in discourse.

\section{Order parameters of the concept Death}

Death - 1) the state of being dead; 2) an occasion when someone dies 3 ) the time when something ends or the fact that it ends (Deth, 2018).

The concept: death;

Motion / state: the end of life;

Localization in time: the end of the "earthly life" of a person;

Localization in space: the universe;

The character of the movement / state: the stop of the life

Participant: mortal man;

Predictability: unpredictability, imminence;

Result: the end of life;

The analysis of metaphorical utterances with the target-domain "death" allows us to conclude that T. Pratchett $(1983 ; 1987 ; 1994 ; 1998)$ associates the concept "death" primarily with an anthropomorphic, conventional image of death - Grim reaper.

\section{Order parameters of the concept Grim reaper}

Grim reaper - an imaginary character who represents death; "a name given to Death in stories and literature. He is shown in pictures as a human skeleton in long black clothes that also cover his head, carrying a large scythe (=a tool for cutting crops)" (Grim reaper, 2018).

The concept: an anthropomorphic image of a reaper with a scythe;

Movement / state: appearance before the death of a person;

Characteristic: an ominous image, suggestive of fear;

Localization in space: "the kingdom of the dead";

Symbol: death;

Purpose: to accompany people to the "next world." 
Accompanying elements: braid / sickle, skeleton, black robes with a hood, fear, death;

Through personification, the author creates an anthropomorphic image of death as GRIM REAPER with a scythe that materializes at the time of the death of a person.

The following metaphorical units present a personified image of the concept of death in the literary discourse of T. Pratchett $(1983 ; 1987 ; 1994 ; 1998)$ :

1) It had to be Death. No one else went around with empty eye sockets and, of course, the scythe over one shoulder was another clue (Pratchett, 1983).

2) The fact that later on, her house collapsed in flames, she herself died in a freak landslide in the Morpork Mountains, proves that Death, too, has a sense of humor (Pratchett, 1983).

3) It's said that when a wizard is about to die Death himself turns up to claim him (instead of delegating the task to a subordinate, such as Disease or Famine, as is usually the case) (Pratchett, 1983).

4) So it was secret at the heart of it all: to look death right in the face and charge (Pratchett, 1994).

5) Then Death remembered what was due to happen later that night. It would not be true to say that Death smiled, because in any case His features were perforce frozen in a calcareous grin (Pratchett, 1983).

6) She'd seen the shadow of death came for him (Pratchett, 1998).

When describing death, and in particular its approximation, T. Pratchett $(1983 ; 1987$; 1994 ; 1998) uses metaphors associated with the sudden appearance of a conventional image of a reaper with a scythe that appears before someone's death: to turn $\boldsymbol{u}$ to claim wizards, to walk into the jaws of Death to look Death to the right of the face, to see the shadow of death, etc.

\author{
Generic space: \\ Death-Grim Reaper; \\ Death's sense of humor-odd / absurd death; \\ to turn up to claim - to be about to die; \\ Calculous grin of Death-inevitable death; \\ to walk into the jaws of Death - to die; \\ to look death right in the face - to be in danger; \\ to see the shadow of Death - to be about to die
}

\title{
Order parameters of the blend DEATH - GRIM REAPER:
}

The concept: an anthropomorphic image of a GRIM REAPER with a scythe;

Motion / state: appears at the time of death / at the time of extreme danger, therefore introduces heroes of works in horror;

Characteristic: imminence, unexpectedness, untimely, impartiality;

Localization in time: appears at the moment of someone's death

Localization in space: the kingdom of the dead;

Symbol: death;

Predictability: untimely, unexpected, and inevitable;

Purpose: to accompany people to the "next world."

As a result of this integration, we observe the formation of a new concept - a blend which generates a number of specific characteristics of the concept "death," namely inevitability, untimeliness, unbiasedness as it may affect anyone (wizards and ordinary people), unpredictability, fear, etc.

At the level of interpretation, "death" is perceived as a skeleton with a scythe, presaging the death of people at the time of utmost danger or risk. The classic image of death, presented by T. Pratchett $(1983 ; 1987 ; 1994 ; 1998)$ in the works of the first and second cycles, has a negative connotation. Grim reaper is often perceived as an 
"executioner," depriving people of lives, so its materialization horrifies the characters. However, we should admit that the image of death as Grim reaper with a scythe is conventional and stereotypical as it is often found in the European literature and mythology.

The works of later cycles, in particular, the cycle "Death," represent Grim reaper in a completely different light:

1) It is a fact that although the Death of the Discoworld is, in his own words, an anthropomorphic personification, he long ago gave up using the traditional skeletal horses, because of the bother having to stop all the time to wire bits back on (Pratchett, 1987).

2) Death's garden was neat, big and well-tended. It was also very, very black (Pratchett, 1987).

3) What was your job again? said Lezek, talking to a black-robed skeleton without showing even a flicker of surprise (Pratchett, 1987).

I USHER SOULS INTO THE NEXT WORLD, said Death (Pratchett, 1987).

4) The wizards were rather surprised to see that Death was wearing an apron and holding a small kitten.... The kitten, however, he put down very carefully and gently pushed away with his foot (Pratchett, 1987).

5) Death must be the loneliest creature in the universe, in the great party of creation, he was always in the kitchen (Pratchett, 1987).

\section{Generic Space:}

Death - Kind Reaper;

Death of people - transfer into the "other world"; to us her souls into the "other world" - Death's job;

Kingdom of Death - neat, well-tended garden;

\section{Order parameters of the blend DEATH - KIND REAPER:}

The concept: an anthropomorphic image of a reaper with a scythe;

Motion / state: appears at the time of death / utmost danger;

Characteristic: a friendly image of Grim Reaper who does his job accompanying people to the "next world."

Localization in time: appears at the moment of someone's death

Localization in space: the garden of Death

Symbol: death;

Predictability: due time

Purpose: to do his job

Accompanying elements: skeleton, black robe with a hood, scythe, garden, pets, apron, and kitchen.

In these metaphors, the classic grim image of death with a scythe is significantly enriched with a number of discursive meanings. According to the author's intention, many human qualities are inherent in death. In everyday life, this character is economic and practical, keeps pets, which he treats with affection. In addition, he often goes out, visits restaurants and parties, where he manages to be the kitchen. At the same time, death is a solitary character, as people are still afraid to meet him "face to face."

We believe that the image of Grim reaper gradually transforms into the image of a friendly character "Kind reaper," who does his job ushering people into the "other world."

At the level of discourse the metaphorical model DEATH - GRIM REAPER (DEATH - KIND REAPER) is implemented along the fractal trajectory "tree." The 
tree-like trajectory is characterized by the stable development of meaning at the beginning and its gradual branching afterwards.

\section{DEATH - KIND / GRIM REAPER}

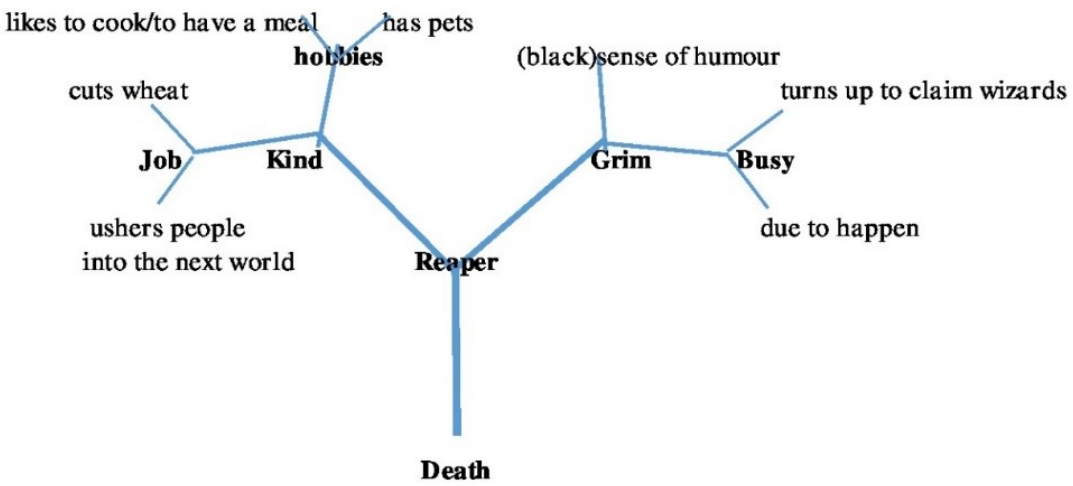

\section{Figure 1: The fractal trajectory "tree": DEATH - KIND / GRIM REAPER}

The initial development of meaning is characterized by the state of equilibrium when the death is associated with the sinister conventional character Grim reaper who deprives people of their lives. He has an ominous sense of humor, which manifests itself in absurd deaths of people. However, later we find out that Grim reaper appears to be a harmless, friendly character - Kind reaper. He has harmless hobbies: cooking, pets, parties, etc., although at the same time he proceeds with his job and warns people about the approach of death. In the synergetic sense, the stability of the initial meaning perception is replaced by the stage of disequilibrium when the meaning appears to have a dual nature.

\section{Conclusion}

Thus, we may draw the following conclusions.

First, we should admit that synergetic principles are quite applicable in linguistics since its object of study - language is a synergetic system by its nature. In fact, it possesses such properties as openness, dissipativity, non-linearity, and others.

Secondly, synergetics gives new perspectives on metaphor study as its mechanism lies in the synergetic non-linear integration of two or more domains. That results in the formation of a new conceptual unit - a blend that in its turn possesses new features.

Thirdly, at the level of discourse, we may observe certain regularities of meaning development. The trajectories of metaphorical meaning-making can be modeled with the help of fractals: spiral, tree, and rhizome.

Finally, we may conclude that the concept "Death" is unfolded along the tree-like trajectory in the literary discourse of T. Pratchett $(1983 ; 1987 ; 1994 ; 1998)$, as in the course of development it appears to have a dual nature.

\section{Bibliographic references}

BARANOV, A.N. 2003. O typakh sochetaemosti metaforicheskikh modelei. In: Voprosi yazikoznania, vol. 2, pp. 73-94. ISSN: 0373-658X.

BOBYREVA, E.V. - DMITRIEVA, O.A. - ZHELTUKHINA, M.R. - BUSYGINA, M.V. 2017. Principle "Understanding" from Perspective of Linguistic Investigations 2017. In: Advances in Social Science, Education and Humanities Research, vol. 97, pp. 52-56. ISSN: 2352-5398. 
BUDD, M. 2006. The Characterization of Aesthetic Qualities by Essential Metaphors and Quasi-Metaphors. In: British Journal of Aesthetics, vol. 46, n. 2, pp. 133-143. ISSN 0007-0904.

CABALlERO, R. 2003. Metaphor and Genre: the Presence and Role of Metaphor in the Building Review. In: Applied Linguistics, vol. 24, n. 2, pp. 145-167. ISSN 01426001.

DAVYDYUK, Y. - PANASENKO, N. 2016. Figuring the Male and Female: Fire and Water in Bradbury's Fiction. In: The Journal of University of SS Cyril and Methodius in Trnava, vol. 1, pp. 4-74. ISSN 2453-8035.

DEATH. 2018. In: Macmillan English Dictionary and Thesaurus. Free English dictionary online. Available online: http://www.macmillandictionary.com/.

DIJK, T.A. 2002. Political Discourse and Ideology. Paper contributed to Jornadas sobre el Discurso Político. Barcelona: Institut Universitari de Lingüística Aplicada. ISBN: 84-477-0800-4.

FAUCONNIER, G. - TURNER, M. 2002. The Way We Think: Conceptual Blending and the Mind's Hidden Complexities. New York: Basic Books. ISBN 0-465-08785-X. FAUCONNIER, G. 1997. Mappings in Thought and Language. Cambridge: Cambridge Univ. Press. ISBN 052146062 X.

GOLUBKOVA, O.N. - MASALIMOVA, A.R. - BIROVA, J. 2017. The Development of Sociocultural Competence in Future Translators Via the Methodology of Culture-Oriented Interpretation of English Language Fictional Texts. In: Man In India, vol. 97, n. 14, pp. 73-83. ISSN: 00251569.

GONDA, D. - EMANOVSKY, P. 2017. The contribution of teaching logic to ethical decision making. In: Communications, vol. 19, n. 1, pp. 126-130. ISSN 1335-4205.

GRECMANOVA, H. - DOPITA, M. - URBANOVSKA, E. 2017. Ethical aspects of communication in the academic environment. In: Communications, vol. 19, n. 1, pp. 25-29. ISSN 1335-4205.

GRIM REAPER. 2018. In: Longman Dictionary of Contemporary English Online. Available online: https://www.ldoceonline.com/dictionary/grim-reaper.

HAKEN, H. 1983. Advanced Synergetics: Instability Hierarchies of Self-organizing Systems and Devices Springer. Berlin: Springer-Verlag. ISBN 978-3-642-45555-1.

HILBORN, R.C. 2004. Sea Gulls, Butterflies, and Grasshoppers: A brief History of the Butterfly Effect in Nonlinear Dynamics. In: American Journal of Physics, vol. 72, n. 4, pp. 425-427. ISSN 0002-9505.

JAMIESON, K.H. - CAMPBELL, K.K. 1997. The Interplay of Influence: News, Advertising, Politics and Mass Media. Belmont: Wadsworth Publishing Company. ISBN 9780534533649.

KOHLER, G.A. - PIOTROWSKI, R.G. 2005. Quantitative Linguistik. New York: Walter de Gruyter. ISBN 3-11-015578-8.

KÖHLER, G.A. 2005. Synergetic Linguistics. Synergetic Linguistics. In: Köhler, G.A. \& R.G. Piotrowski (Eds.). Quantitative Linguistik. Ein internationales Handbuch. Quantitative Linguistics. An International Handbook. New York: Walter de Gruyter, 760-775. ISBN 3-11-015578-8.

LAKOFF, G. - JOHNSON, M. 2003. Metaphors We Live by. Chicago: University of Chicago Press. ISBN: 0-226-46801-1.

LEVINSON, S.C. 1983. Pragmatics. Cambridge: Cambridge University Press. ISBN 978-0521294140.

LI, N. - PYRKOVA, K.V. - RYABOVA, T.V. 2017. Teaching Communication Skills and Decision-Making to University Students. In: EURASIA Journal of Mathematics, Science and Technology Education, vol. 13, n. 8, pp. 4715-4723. ISSN: 1305-8215.

MURYASOV, R.Z. - SAMIGULLINA, A.S. 2013. Metaforicheskie modeli gordosti $\frac{\mathrm{v} \text { britanskoy lingvokulture: korpusno-orientirovannyi podkhod. Vestnik }}{\text { XLinguae, Volume 11, Issue 3, June 2018, ISSN 1337-8384, eISSN 2453-711X }}$ 
Chelyabinskogo gosudarstvennogo universiteta, vol. 10, n. 301, pp. 68-75. ISSN: 1994-2796.

NERLICH, B. - CLARKE, D.D. 2001. Mind, Meaning, and Metaphor: the Philosophy and Psychology of Metaphor in 19th-Century Germany. In: History of the Human Sciences, vol. 14, n. 2, pp. 39-61. ISSN 0952-6951.

PARTHASARATHY, K.R. 1988. Obituary: Andrei Nikolaevich Kolmogorov. In: Journal of Applied Probability, vol. 25, n. 2, pp. 445-450. ISSN 0021-9002.

PRATCHETT, T. 1983. The Colour of Magic. London: Corgi Books. ISBN: 9780552555593

PRATCHETT, T. 1987. Mort. London: Corgi Books. ISBN: 9780552555593

PRATCHETT, T. 1994. Interesting Time. London: Corgi Books. ISBN: 9780552555593

PRATCHETT, T. 1998. Carpe Juglum. London: Corgi Books. ISBN: 9780552555593 PRIGOGINE, I. - STENGERS, I. 1984. Order out of Chaos: Man's New Dialogue with Nature. Toronto: Bantam Books. ISBN 0553340824.

RAYMOND, C.M. - SINGH, G.G. - LEVINE, J. - TAM, J. - CHAN, K.M.A. BERNHARDT, J.R. - NELSON, H. - BENESSAIAH, K. - TURNER, N.J. NORTON, B. 2013. Ecosystem Services and Beyond: Using Multiple Metaphors to Understand Human-Environment Relationships. In: Bioscience, vol. 63, n. 7, pp. 536546. ISSN 0006-3568.

RIXON, P. 2014. Popular Newspaper Discourse. In: Journal of Historical Pragmatics, vol. 15 , n. 2, pp. 314-330. ISSN 1566-5852.

SAMIGULLINA, A.S. - BAKIEV A.G. 2014. Metaphora I discursivnoye soznanye. In: Kazanskaya Nauka, vol. 3, pp. 174-179. ISSN: 2078-9955.

STEGER, T. 2007. The Stories Metaphors Tell: Metaphors as a Tool to Decipher Tacit Aspects in Narratives. In: Field Methods, vol. 19, n. 1, pp. 3-23. ISSN 1525$822 \mathrm{X}$.

STRAUSS, D. 2014. Ideological Closure in Newspaper Political Language during the U.S. 1872 Election Campaign. In: Journal of Historical Pragmatics, vol. 15, n. 2, pp. 255-291. ISSN 1566-5852.

TANTUCCI, V. 2016. Toward a Typology of Constative Speech Acts. In: Intercultural Pragmatics, vol. 13, n. 2, pp. 181-209. ISSN 1612-295X.

TARDE, G. 1969. On Communication and Social Influence. Chicago: University of Chicago Press. ISBN 0226789713.

THOMPSON, J. 1995. The Media and Modernity: A Social Theory of the Media. Cambridge: Polity Press. ISBN: 9780804726795.

THORNBURY, S. 1991. Metaphors We Work by: EFL and its Metaphors In: ELT Journal, vol. 45, n. 3, pp. 193-200. ISSN 0951-0893.

VHENTTONEN, L. - HENTTONEN, P. - KAHRI, M. - KIVIOJA, M. - RAVAJA, N. - SAMS, S. - PERAKYLA, A. 2014. Affective Stance, Ambivalence, and Psychophysiological Responses during Conversational Storytelling. In: Journal of Pragmatics, vol. 68, pp. 1-24. ISSN: 0378-2166.

VODAK, R. 1997. Yazyk. Diskurs. Volgograd: Peremena. ISBN 5-88234-249-X.

ZHELTUKHINA, M.R. - MAGOMADOVA T.D. 2015. Metaforicheskie modeli v ramkax metaforicheskogo modelirovaniya «POLITIKA» - «VOJNA» v anglijskom, nemeczkom i russkom mediadiskurse XXI veka. In: Kognitivny`e issledovaniya yazy'ka, vol. 21, pp. 218-224. ISSN 2071-9639.

ZHELTUKHINA, M.R. - SLYSHKIN, G.G. - PONOMARENKO, E.B. BUSYGINA, M.V. - OMELCHENKO, A.V. 2016. Role of Media Rumors in the Modern Society. In: International Journal of Environmental and Science Education, vol. 11, n. 17, pp. 10581-10589. ISSN 1306-3065.

ZHELTUKHINA, M.R. - VIKULOVA, L.G. - KOVALEVA, N.A. RYANSKAYA, E.M. - FOMINA, ZH.V. 2017. Symbolic Nature of Culture: Features 
of the English Floristic Symbolics in Modern Economic and Political Media Texts. In: Man in India, vol. 97, n.14, pp. 61-71. ISSN: 0025-1569.

Words: 5173

Characters: 34234 (19 standard pages)

Prof. Rakhim Zakievich Muryasov, Dr. of Philology

Department of Romance and Germanic Philology

Bashkir State University

32 Zaki Validi Street

450076 Ufa

Russia

lingua_anna@mail.ru

Associate Prof. Anna Sergeevna Samigullina, Dr.

Department of Romance and Germanic Philology

Bashkir State University

32 Zaki Validi Stree

450076 Ufa

Russia

lingua_anna@mail.ru

Assistant Prof. Andrey Gavrilovich Bakiev PhD.

Department of Romance and Germanic Philology

Bashkir State University

32 Zaki Validi Street,

450076 Ufa

Russia

anbakiev@yandex.ru 